\title{
Impediments for University Teachers and Students in the Usage of Information and Communication Technology
}

\author{
${ }^{1}$ Fauzia Khurshid, ${ }^{2}$ Shandana
}

\begin{abstract}
This research was intended to discover the impediments for teachers and students in the usage of information communication technologies (ICT) in public and private sectors universities of Islamabad. Main objectives of the study were to identify the impediments in the usage of ICT in private and public sectors universities and to explore the teachers and students' demographic variation in their usage of ICT in the private and public sectors universities. Stratified random sample of 40 teachers and 60 students was collected from 2 public and 2 private universities of Islamabad. Results revealed that at present university teachers and students are facing several impediments in their usage of ICT in the teaching and learning process. Study also found that teachers having M. Phil qualification and students studying in $\mathrm{PhD}$ programmes are facing more impediments in their usage of ICT. Comparative analysis of ICT impediments in the private and public sector universities revealed that teachers and students of private sector universities are facing more impediments in their usage of ICT as compared with teachers \& students of public sectors universities. Findings of the study would be useful for the management of private and public sector universities in order to remove the impediments in the usage of ICTs.
\end{abstract}

Keywords: Impediments, Information and Communication Technology

\section{Introduction}

During last twenty five years man has achieved tremendous success in the field of Information and Communication Technology. The volume of information is growing rapidly and it is expected that in every five years, the volume of information is going to be doubled.ICT (information and communication technology)are diverse set of technological tools and resources, used to handle information and communication. It includes any communication application or device e.g. computer, internet, cellular phone, broadcasting technology (radio, TV) satellite system as well as the various service and application associated with them such as distance learning and video

\footnotetext{
${ }^{1}$ Visiting Faculty, National University of Modern Languages, Islamabad Email: National University of Modern Languages

${ }^{2}$ Research Scholar, Department of Education, National University of Modern Languages
} 
conferencing. ICTs have ability to accelerate, innovate, enrich and motivate students' skills. It also has ability to strengthen teaching because it increases flexibility in deliverance of education and enables students to obtain knowledge anywhere and anytime. It focuses on the students' perspective that how they learn and how they are taught. The process is driven by students not by teachers. This change would prepare students for long life as well as enhance the effective learning. It transfers content from content centred to competence based paradigm. The delivery mode of curricula has now shifted from teacher centred to student centred form of delivery (Kumpulainen, 2007).

Present era is the era of information explosion, information is transmitting too faster that even a literate person feels that he or she is illiterate and unable to cope up with such explosive information. Here, the question arises that how a person can cope up with it? The answer is information technology, which is coping with such explosive information. It consists of two words information and technology. The term information is directed to any communication or representation of knowledge such as facts, data or opinion in any medium or for including numerical, textual, graphic cartographic, narrative or audio-visual form. Technology is the practical form of scientific knowledge or the science of application of knowledge into practical mode. The emergence of this new global economy has serious implications for the nature and purpose of educational institutions. As the access to information continues to grow rapidly, schools cannot be contented with the limited knowledge to be transmitted in a fixed period of time. They have to become compatible to the ever expanding knowledge and also be equipped with the technology to deal with this knowledge. Information and communications technology (ICT) is often used as an extended synonym for information technology (IT), but is a more specific term that stresses the role of unified communications and the integration of telecommunications (telephone lines and wireless signals), computers as well as necessary enterprise software, middleware, storage, and audio-visual systems, which enable users to access, store, and manipulate information (Venkatesh, Morris \& Davis,2003).

Pelgrum (2001) stated that IT gained the position of term computer near the end of 1980s which signify a transformation of focus from computing technology to the ability to store and retain information. Educational field is influenced by ICTs which directly affect research, teaching and learning. ICTs have capability to enrich and accelerate the abilities and skills of the students. ICTs motivate the student to do by themselves i.e. they don't depend on the teachers which in turn motivates the students to be engaged in different learning activities. Furthermore, ICTs strengthen the teaching, learning process. In 
scientific world, where new inventions are invented day by day in this era, fundamental education is necessary for the learners to enable them to get and apply this information. In traditional teaching more emphasis was laid on the content and for many decades course had been written in books only. Teachers have taught through presentation and lectures collected through learning and tutorial activities designed to rehearse the content.

ICT has removed communication barriers, it allows for the creation of digital tools like digital libraries where professionals, learners and teachers can take research material from anytime and anywhere. It simply removes geographical barriers. It improves quality of education, to give direction to teachers in their professions and help students to teach more effectively (Hennessy, 2010). But unfortunately there are many hurdles found in the use of ICT in private and public sector universities. These hurdles are as follows: Lack of competence and skills, lack of internet facilities, lack of computers facilities and lack of technical support.

Today, universities are focusing more on the curriculum that enhances students' performance and competency. At present ICTs are able to support all these needs and there are many examples of performance and competency based curriculum that make intellectual use of these affordable technologies. Information communication technology can help both the teacher and students in teaching learning processes. Through this, ICT improves the quality of education. According to Haliso (2004) the flexibility of time and place is calculated by the integration of information and communication technology in the teaching learning environment which brings to accelerate the communication and receipt of information. Such possibilities suggest change in the teaching learning processes and in communication models giving a new path which is favourable to both learner and cooperative learning. In educational setting, ICTs act like a catalyst; as in chemistry role of catalyst is to speed up the reaction, same is the case with ICTs that can facilitate each learner and improve the quality of education. Information communication technology tool is very effective as it encourages the learners to get education by themselves and it also makes the learners independent from the concept of spoon feeding knowledge as happened in past traditional system of teaching learning process. Now students are using ICTs tool in their learning processes and more and more students are using ICT tools as cognitive tools (Jones, 2004).

Just as the technology is supporting and predominating what is being learned in universities and other learning institution so is too influencing change to the way learners are learning. It changes the learning pattern from content curriculum to competency curriculum and teacher centred form of teaching to 
student centred forms. Through technology facilitated approaches, today's learning intends to boost up the students to take responsibility of their own learning. The advancement of technology and its extensive use in every field specifically in education field brought major transformation. Application of information communication technology provides many choices and options and these choices extend from when and where the learner can choose to learn. ICTs promote the flexibility of deliverance of education, so the learner gets the knowledge at any place (Ougunsola \& Abuyade, 2005).

The introduction of ICTs into teaching learning process is very complex process due to certain problems which are known as impediments. These impediments can be defined as "Any environment that makes it difficult to make progress or to obtain objectives". Pelgrum (2001) classified impediments at teaching and institutional level; teaching level impediments include lack of confidence, time and resist to change whereas, institution level impediments include lack of access to recourses, lack of effective training in order to solve the technical problem. He further classified two types of impediments known as material and non-material, the material condition includes copies of software and insufficient numbers of computers. The non-material barrier contains teacher's insufficient ICTs skills and knowledge and insufficient teacher's time. Sometimes teacher have fear while using the equipments, fear mainly concern with damage of equipments. When a teacher has this sort of fear he directly loses his confidence level. For example; if a teacher uses computer in his lecture in the same time he has fear of the damage of hardware. This is the main cause that makes the teachers avoid from the ICTs. The above description is about barrier in the use of ICTs that how it causes the fear in teacher i.e. this barrier of ICT is the damage of equipments. Other thing is unavailability of technician on learning place. Sometimes institutes have the equipments but have some technical problems, and they remain unsolved as there are no proper technicians.

One of the factors which create impediments in the implementation of ICT in any institution is the network connection; if not reliable it can be disconnected at any moment. The cause for network being not connected could be the web server, cabling network problem, virus or hacker attacker. This demotivates and frustrates both teacher and the students during the teaching learning process. In education system the effective use of ICT contain substantial funding, that is hard to manage in developing countries like Pakistan. As ICT supported software, hardware, audio visual aids, internet and teaching aids demand huge funds therefore, present study designed to gather information regarding the impediments for university teachers and students in the usage of ICTs. 


\subsection{Statement of Problem}

The problem of the study included to explore impediments for teachers and students in the usage of ICTs. It further aimed to investigate the role of students and teachers' demographic variations of gender and qualification in determining their perceived level of ICTs impediments in the private and public sectors universities of Islamabad.

\subsection{Objectives of the Study}

1. To identify the impediments in the usage of ICT in private and public sectors universities of Islamabad.

2. To explore the students and teachers demographic variations of gender and qualification in determining their perceived level of ICT impediments in the context of private and public sectors universities of Islamabad.

\subsection{Hypotheses}

1. Male university teachers are facing more impediments in their usage of ICTs as compared to female teachers.

2. Male university students are facing more impediments in their usage of ICTs as compared to female teachers.

3. Students doing $\mathrm{PhD}$ are facing more impediments while using ICTs as compared to students of Master and M. Phil level.

4. Teachers of private sector universities are facing more impediments in their usage of ICTs as compared to teachers of public sector universities.

5. Students of private sector universities are facing more impediments in their usage of ICTs as compared to students of public sector universities.

\subsection{Sample}

\section{Research Methodology}

Data were collected through stratified random sampling technique by dividing population in to two parts, public sector and private sector. A stratified random sample of 100 individuals was collected; among them 40 were faculty members and 60 were students. Data were collected from 4 universities (2public sector and 2 private sector) located at Islamabad.

\subsection{Research Instruments}

Two separate research questionnaires were developed i.e. one for teachers and the other for students. For the measurement of impediments in the usage of ICTs among public and private sector universities, teachers' questionnaire comprising of 24 items and four subscales were used namely Impediments faced by Teachers, Management Attitude, Lack of ICT Awareness and Lack of ICT Tools. For the measurement of impediments in the usage of 
ICTs among public and private sector universities, students' questionnaire comprising of 20 items and four subscales were used names of subscales are Impediments faced by students, Management Attitude, lack of ICT Tools and Lack of ICT Awareness.

\subsection{Data Collection}

Data were collected from 4 universities of Islamabad after taking permission from respective authorities. Teachers and students were contacted individually at their respective staff rooms and classrooms. Furthermore, they were requested to fill in the questionnaire according to their own point of view keeping in view the impediments in their usage of ICTs at campus.

\section{Results}

After collecting the data, whole data were transferred to computer with the help of software SPSS 16. Various statistical tests were used including Mean and Standard Deviations and analysis of Variance. Alpha Reliability coefficients were determined for both questionnaires.

Table 1

Mean, Standard Deviation and t-test of University Teachers on Impediments in the usage of ICT Questionnaire in relation to Variable Gender $(\mathrm{N}=40)$

\begin{tabular}{|c|c|c|c|c|c|}
\hline & \multicolumn{5}{|c|}{ GENDER } \\
\hline \multirow{4}{*}{$\begin{array}{l}\text { Subscale of ICT } \\
\text { Impediments } \\
\text { Questionnaire }\end{array}$} & \multicolumn{2}{|c|}{ Male } & \\
\hline & \multirow{2}{*}{\multicolumn{2}{|c|}{$\begin{array}{l}\text { University } \\
\text { Teachers } \\
(\mathrm{N}=17)\end{array}$}} & \multirow{2}{*}{\multicolumn{3}{|c|}{$\begin{array}{l}\text { Female University Teachers } \\
\qquad(\mathrm{N}=23)\end{array}$}} \\
\hline & & & & & \\
\hline & $\mathrm{M}$ & SD & $\mathrm{M}$ & SD & $\mathrm{t} \quad$ sig \\
\hline $\begin{array}{l}\text { Difficulty faced by } \\
\text { Teachers }\end{array}$ & 24.6 & 4.2 & 24.4 & 3.5 & \\
\hline $\begin{array}{l}\text { Management } \\
\text { Attitude }\end{array}$ & 13.2 & 4.1 & 12.1 & 3.2 & \\
\hline $\begin{array}{l}\text { Lack of ICT } \\
\text { Awareness }\end{array}$ & 21.7 & 4.0 & 19.0 & 4.7 & 3.9 .02 \\
\hline Lack of ICT Tools & 7.4 & 1.8 & 6.7 & 1.4 & \\
\hline Total & 67.0 & 14.1 & 62.3 & 12.8 & \\
\hline
\end{tabular}

Table 1 shows the Mean and Standard Deviation of private and public sector universities on impediments in the use of ICT for the variable Gender. Result indicates that male university teachers are facing more impediments in their usage of ICTs as compared to female university teachers. 
Table 2

Mean, Standard Deviation and t-test of University Students on Impediments in the usage of ICT Questionnaire in relation to Variable Gender $(\mathrm{N}=40)$

\section{Gender}

\begin{tabular}{|c|c|c|c|c|c|}
\hline \multirow[t]{2}{*}{$\begin{array}{l}\text { Subscale of ICT } \\
\text { Impediments } \\
\text { Questionnaire }\end{array}$} & \multicolumn{2}{|c|}{$\begin{array}{c}\text { Male } \\
\text { University students } \\
(\mathrm{N}=25)\end{array}$} & \multicolumn{3}{|c|}{$\begin{array}{c}\text { Female } \\
\text { University Students } \\
(\mathrm{N}=35)\end{array}$} \\
\hline & M & SD & M & SD & $\mathrm{t} \quad \mathrm{sig}$ \\
\hline $\begin{array}{l}\text { Difficulty faced by } \\
\text { student }\end{array}$ & 14.6 & 3.0 & 14.4 & 3.6 & \\
\hline $\begin{array}{l}\text { Management } \\
\text { Attitude }\end{array}$ & 12.8 & 2.9 & 12.2 & 3.5 & \\
\hline $\begin{array}{l}\text { Lack of ICT } \\
\text { Awareness }\end{array}$ & 18.2 & 3.1 & 15.2 & 3.6 & 3.5 .01 \\
\hline Lack of ICT Tools & 8.2 & 1.4 & 6.8 & 1.5 & \\
\hline Total & 53.8 & 7.7 & 48.6 & 9.5 & \\
\hline
\end{tabular}

The table 2 shows the Means and Standard Deviation of private and public sectors universities on questionnaire for the variable Gender. Result indicates that male university students are facing more impediments in their usage of ICTs as compared to female university students.

Table 3

Mean, Standard Deviation and t-test of University Teachers on Impediments in the usage of ICT Questionnaire in relation to Variable Qualification $(\mathrm{N}=40)$

\begin{tabular}{|c|c|c|c|c|c|c|}
\hline \multicolumn{7}{|c|}{ Qualification } \\
\hline \multirow{2}{*}{$\begin{array}{l}\text { Subscale of ICT } \\
\text { Impediments } \\
\text { Questionnaire }\end{array}$} & \multicolumn{2}{|c|}{$\begin{array}{l}\text { Master } \\
(\mathrm{N}=12)\end{array}$} & \multicolumn{2}{|c|}{$\begin{array}{l}\text { M.Phil } \\
(\mathrm{N}=23)\end{array}$} & \multicolumn{2}{|c|}{$\begin{array}{c}\mathrm{PhD} \\
(\mathrm{N}=5)\end{array}$} \\
\hline & $\mathrm{M}$ & SD & M & SD & M & SD \\
\hline $\begin{array}{l}\text { Impediments faced } \\
\text { by Teachers }\end{array}$ & 22.5 & 2.9 & 26.1 & 3.7 & 22.2 & 2.2 \\
\hline $\begin{array}{l}\text { Management } \\
\text { Attitude }\end{array}$ & 12.5 & 3.2 & 13.1 & 4.1 & 10.4 & 1.1 \\
\hline $\begin{array}{l}\text { Lack of } \\
\text { Awareness }\end{array}$ & 6.5 & 1.8 & 7.6 & 1.4 & 5.6 & 0.5 \\
\hline $\begin{array}{l}\text { Lack of } \\
\text { Tools }\end{array}$ & 18.7 & 2.9 & 21.1 & 5.1 & 18.8 & 4.7 \\
\hline Total & 60.3 & 7.0 & 68.0 & 1.1 & 57.0 & 4.3 \\
\hline
\end{tabular}


Table 3 shows Means and Standard Deviation of private and public sectors universities teachers' scores for the variable Qualification. Result indicates that teachers who are having $\mathrm{M}$. Phil degrees are facing more impediments in the usage of ICT as compared to teachers having Master and $\mathrm{PhD}$ degrees.

Table 4

Analysis of Variance of Students Scores on Impediments in the usage of ICT Questionnaire in relation to Variable Qualification $(\mathrm{N}=40)$

\begin{tabular}{lrrrrr}
\hline ANOVA & & Df & Mean Square & F & Sig \\
\hline ICT & Between groups & 2 & 20.305 & 4.288 & \\
& Within groups & 37 & 87.595 & & .021 \\
& Total & 39 & & & \\
\hline
\end{tabular}

$\mathrm{P}<0.05^{* *}$

Table no 4 shows that there is a significant difference between response of teachers on impediments in the usage of ICT questionnaire the value of $\mathrm{F}=$ 4.288 and level of significance is .021 .

Table 5

Mean, Standard Deviation and t-test of University Students on Impediments in the usage of ICT Questionnaire in relation to Variable qualification $(\mathrm{N}=40)$

\begin{tabular}{|c|c|c|c|c|c|c|}
\hline \multicolumn{7}{|c|}{ Qualification } \\
\hline $\begin{array}{l}\text { Subscale of ICT } \\
\text { Impediments }\end{array}$ & \multicolumn{2}{|c|}{$\begin{array}{l}\text { Master } \\
(\mathrm{N}=34)\end{array}$} & \multicolumn{2}{|c|}{$\begin{array}{l}\text { M. Phil } \\
(\mathrm{N}=20)\end{array}$} & \multicolumn{2}{|c|}{$\begin{array}{c}\mathrm{PhD} \\
(\mathrm{N}=6)\end{array}$} \\
\hline Questionnaire & $\mathrm{M}$ & SD & M & SD & $\mathrm{M}$ & SD \\
\hline $\begin{array}{l}\text { Impediments faced by } \\
\text { students }\end{array}$ & 14.7 & 3.7 & 13.7 & 3.0 & 16.0 & 2.2 \\
\hline Management Attitude & 12.5 & 3.4 & 11.6 & 2.7 & 14.8 & 3.9 \\
\hline Lack of ICT Awareness & 16.4 & 3.8 & 15.3 & 2.9 & 16.3 & 3.8 \\
\hline Lack of ICT Tools & 7.0 & 1.6 & 7.0 & 1.5 & 6.6 & 1.0 \\
\hline Total & 50.7 & 1.0 & 47.7 & 6.4 & 53.8 & 7.3 \\
\hline
\end{tabular}

Table 5 shows the qualification wise differences in the Means and Standard Deviation of private and public sectors universities students' scores. Result indicates that students doing $\mathrm{PhD}$ are facing more impediments in their usage of ICT as compared to Master and M. Phil students. 
Table 6

Analysis of Variance of Students' Scores on Impediments in the usage of ICT Questionnaire in relation to Variable Qualification $(\mathrm{N}=60)$

\begin{tabular}{lccccc}
\hline ANOVA & & Df & $\begin{array}{c}\text { Mean } \\
\text { Square }\end{array}$ & F & Sig \\
\hline ICT & Between groups & 2 & 18.05 & 3.78 & .034 \\
& Within groups & 58 & 82.57 & & \\
& Total & 60 & & & \\
\hline $\mathrm{P}<0.05^{* *}$ & & & & &
\end{tabular}

Table 6 shows that there is a significant difference between response of teachers on ICT at value of $\mathrm{F}=3.78$ and level of significance is .034.

Table 7

Mean, Standard Deviation and t-test of University Teachers on Impediments in the usage of ICT Questionnaire in relation to Variable Sector $(\mathrm{N}=40)$

\begin{tabular}{|c|c|c|c|c|c|c|}
\hline \multicolumn{7}{|c|}{ Sector } \\
\hline $\begin{array}{l}\text { Subscale of ICT } \\
\text { Impediments }\end{array}$ & \multicolumn{2}{|c|}{$\begin{array}{l}\text { Public } \\
(\mathrm{N}=27)\end{array}$} & \multicolumn{4}{|c|}{$\begin{array}{l}\text { Private } \\
(\mathrm{N}=13)\end{array}$} \\
\hline Questionnaire & M & SD & $\mathrm{M}$ & $\mathrm{SD}$ & $\mathrm{t}$ & sig \\
\hline $\begin{array}{l}\text { Impediments faced by } \\
\text { Teachers }\end{array}$ & 24.6 & 3.7 & 28.3 & 4.1 & & \\
\hline Management attitude & 12.7 & 3.9 & 12.3 & 3.1 & & \\
\hline ICT awareness & 7.1 & 1.7 & 6.9 & 1.4 & 4.6 & .21 \\
\hline $\begin{array}{l}\text { Lack of Availability of } \\
\text { ICT Tools }\end{array}$ & 19.4 & 4.8 & 23.5 & 3.9 & & \\
\hline Total & 64.0 & 14.1 & 71.0 & 12.5 & & \\
\hline
\end{tabular}


Table 8

Mean, Standard Deviation and t-test of University Students on Impediments in the usage of ICT Questionnaire in relation to Variable Sector $(\mathrm{N}=40)$

\begin{tabular}{|c|c|c|c|c|c|c|}
\hline \multicolumn{7}{|c|}{ Sector } \\
\hline $\begin{array}{l}\text { Subscale of ICT } \\
\text { Impediments }\end{array}$ & \multicolumn{2}{|c|}{$\begin{array}{l}\text { Public } \\
(\mathrm{N}=24)\end{array}$} & \multicolumn{3}{|c|}{$\begin{array}{l}\text { Private } \\
(\mathrm{N}=36)\end{array}$} & \\
\hline Questionnaire & $\mathrm{M}$ & $\mathrm{SD}$ & M & $\mathrm{SD}$ & $\mathrm{t}$ & $\mathrm{p}$ \\
\hline $\begin{array}{l}\text { Difficulty faced by } \\
\text { students }\end{array}$ & 13.9 & 3.8 & 17.8 & 3.0 & & \\
\hline Management Attitude & 12.6 & 4.0 & 12.3 & 2.6 & 5.9 & .01 \\
\hline Lack of ICT Awareness & 16.0 & 4.4 & 16.0 & 2.9 & & \\
\hline Lack of ICT Tools & 7.2 & 1.7 & 6.8 & 1.3 & & \\
\hline Total & 49.9 & 17.9 & 53.0 & 6.8 & & \\
\hline
\end{tabular}

The table 8 shows the Means, SD and $t$ value of private and public sectors universities students' scores on impediments in the usage of ICT questionnaire. Result indicates that students of private sector universities are facing more impediments in the usage of ICT as compared to students of public sector universities. A significant difference also exists in the scores.

\section{Findings and Conclusions}

It is general observation that at higher education level in many countries, universities are facing serious challenges in leading to a number of developments in the process of integrating information and communication technologies into practice due to certain barriers. Watson (2002) supported the use of ICT and revealed that teachers do not use it properly. Furthermore, he was of the view that the use of ICT in education is not only a catalyst for change, but also change in teaching style, change in learning approaches and change in access to information. Yet, research indicates that teachers are both threatened by change, and conversely not impressed by change that appears to focus on what the technology can do rather than learning. In this line of thinking, Jones (2002), declared that too many teachers still lack confidence in using ICT and this often made worse by lack of appropriate software, unreliable computers and internet connections and insufficient technical support when things go wrong. Findings of the present study are consistent with these results because in our cultural perspective in the context of IT at university level teachers are facing challenges due to management attitude, lack of ICT tools and lack of their own awareness. 
Nwankwoala (2015) carried out an investigation on lecturers' and students' use of ICTs in Nigerian university education as a panacea for national development. It was conducted in two states owned Universities of Rivers State. Random sampling technique was employed in the selection of 1154 subjects (i.e. 146 lecturers and 1008 students). A 40 items and 20 items self-structured test titled: "Information and communication Technology Usage Scale" (ICTUS) and National Development Inventory (NDI) validated by experts and with a reliability coefficient of 0.763 was used to analyse the data using t-test and regression analysis. Results revealed that the gender of university lecturers did not predict their usage of ICT while it also revealed that ICT usage contributed to national development. It was recommended that the National universities Commission (NUC) should commence an urgent review of the course content of university education, with a view at compulsorily incorporating ICT usage as a standard for all teaching, learning and examinations. As far as gender differences are concerned, according to findings to present study male university teachers and students are facing more difficulties when compared to female teachers and students. Female teachers and students have more awareness of ICTs and have access to ICTs tool more as compared to male teachers and students.

In Pakistan, universities are facing many challenges in the field of ICTs therefore present study planned, so impediments in the use of ICTs in public and private sectors universities of Islamabad can be explored. Results have shown that university teachers and university students are facing challenges in the usage of ICTs due to management attitude, due to lack of ICT tools and due to their own lack of awareness. Results also provided us information that students are facing difficulties in their usage of ICT more due to lack of ICT tools as compared to university teachers.

Followings are conclusions of the study:

1. Male university teachers and male university students are facing more impediments in their usages of ICTs as compared to female university teachers and students.

2. There is significant difference in the impediments' in the use of ICT among public and private university teachers and students. Teachers and students of private sector universities are facing more impediments in their usage of ICTs as compared to students of private sector universities.

3. Teachers having M. Phil degrees, perceived more impediments in their usage of ICTs as compared to teachers having PhD and Masters Degrees. M. Phil teachers faced more difficulties and lack of availability of ICTs tools. Subscales wise analysis revealed that teachers having Master degree are having low scare on Lack of ICT Awareness. 
4. Students doing $\mathrm{PhD}$ are facing more impediments in their usage of ICTs; they are facing more difficulties due to lack of ICTs tools.

\section{Recommendations}

It is a long way to run ICT in an under developing countries like ours however, higher education institutions may show serious concern for the promotion and improvement of ICT software and there should be proper training of teachers to educate them with the use of ICT and its importance in current technological world. Management may ensure the availability of ICT in universities up to the satisfaction level of teachers and students.

1. At present male university teachers and male university students are facing more impediments in their usages of ICTs as compared to female university teachers and students therefore; it is recommended that university management may conduct a baseline survey to get more precise information about impediments existed in the usage of ICTs at campus (specifically for male teachers and students, keeping in view their expectations as well).

2. At present teachers and students of private sector universities are facing more impediments in their usage of ICTs as compared to teachers and students of private sector universities; it is therefore, recommended that management of private sector universities may focus more on the removal of impediments through strengthening ICTs facilities.

3. Teachers having M. Phil degrees, perceived more impediments in their usage of ICTs as compared to teachers having PhD and Masters Degrees. M. Phil teachers faced more difficulties and lack of availability of ICTs tools. Subscales wise analysis revealed that teachers having Master degree are having low score on Lack of ICT Awareness. University management may arrange training for the professionals.

4. Students doing $\mathrm{PhD}$ are facing more impediments in their usage of ICTs; they are facing more difficulties and lack of ICTs tools. Management may focus to provide ICTs related tools to the PhD scholars.

5. Management may hold awareness seminars and training workshops to instruct teachers about the utilization of ICT effectively.

6. Management may ensure well equipped classrooms with latest tools so teachers can utilize ICTs in their teaching \& learning process effectively.

7. Provision of skilled supporting staff would be helpful for students as well as for teachers in case of any trouble.

8. Technology based classes may be arranged, in which teachers \& students could collaborate through internet devices.

9. More ICT-related courses for students may be offered and every ICT-related course may be practice-oriented. For the promotion of ICTs in the teaching 
learning process management may reward to the teachers who are integrating ICTs in their courses (i.e., through incentives)

10. ICT-related courses can be integrated in teaching practice courses. University management may provide at least one computer with Internet access and LCD projector to each class.

11. Management is recommended to ensure the proper utilization and maintenance of ICT tools regularly.

\section{References}

Haliso, Y.( 2011).Factors Affecting Information and Communication Technologies (ICTs) Use by Academic Librarians in Southwestern Nigeria, Library Philosophy \& Practice, 4, 42

Hennessy, S., Onguko, B., Harrison, D., Ang'ondi, E., Namalefe, S., Naseem, A., \& Wamakote, L. (2010).Developing the Use of Information and Communication Technology to Enhance Teaching and Learning in East Africans: Review of Literature. Karachi: Aga Khan University. Retrieved from

http://www.educ.cam.ac.uk/centres/archive/cce/publications/CCE_Repor t1_LitRevJune0210.pdf

Jones, A. (2004). A Review of the research literature on the Barriers to the uptake of ICT by Teachers. British Educational Communications and Technology Agency (Becta). Retrieved from http://dera.ioe.ac.uk/1603/1/becta_2004_barrierstouptake litrev.pdf

Jones, A. (2002). ICT and learning theories: Preparing pre-service teachers for the classroom. Paper presented in Annual Conference of the British Educational Research Association. England: University of Exeter. Retrieved from http://www.leeds.ac.uk/educol/documents/00002496.htm

Kumpulainen, K. (2007). Educational Technology Opportunities \& Challenges. Oulu: Finland University of Oulu.

Nwankwoala, H. N. L. (2015). An Investigation of Lecturers' and students' use of ICTs in Nigerian university education as a panacea for national development Research on Humanities and Social Sciences, 5(2), 167176.

Retrieved from http://www.iiste.org/Journals/index.php/RHSS/article/view/26839/27520 
Ougunsola, L.A., \& Abuyade, W.A. (2005). Information \& communication technology in Nigeria: Revolution or Evolution. Journals of Social Science, 11(1), 7-14.

Pelgrum, W. J. (2001). Obstacles to the integration of ICT in education: result from worldwide educational assessment. Computer \& Education, 37(2), 163-178.

Venkatesh, D., Morris, M. \& Davis, G.B. (2003). User acceptance of information Technology: Toward a unified view, MIS Quarterly, 27 (3), 425-478.

Watson, D. (2001). Pedagogy before Technology: Re-thinking the Relationship between ICT and Teaching. Education and Information Technologies, 6(4), 251-266. Retrieved from https://pdfs.semanticscholar.org/8716/a18fc92e7aef2ce58990490f58f89d 22c535.pdf 